HStud 23 (2009)2, 175-194 DOI: 10.1556/HStud.23.2009.2.2

\title{
SYSTEMS THEORY AND ECOLOGICAL SETTLEMENT DESIGN: A PILOT PROJECT IN RURAL HUNGARY
}

\author{
BÉLA BORSOS \\ Pécs University, Institute of Geography, Pécs \\ Hungary
}

\begin{abstract}
General systems theory is a scientific discipline that adopts a different approach to that of reductionist science, based on systems, connections and processes. The emerging new field of human ecology, which attempts to reconcile natural systems with human-made systems, draws boldly on this wealth of knowledge. One of the methods of facing the challenges of the worldwide ecological crisis is the implementation of the resulting principles of sustainable development at the rural development level. In south-west Hungary, the sparsely populated small village region of Zselic is home to a small-scale sustainable settlement development project in the abandoned former village of Gyürüfü. Over the past fifteen years, principles of ecological design, such as permaculture, dominated the re-settlement of the area by a small number of ecologically conscious city dwellers-turned-villagers. Ecological landscape assessment of the site preceded the actual design of the project, providing the grounds for proper siting and implementation methods of the various facilities. Alternative solutions were applied to the functions of building construction, building engineering, water management, agriculture, sewage treatment, waste management and gardening, and a community-based social structure to strengthen ecological values. The project survived in spite of the dramatically changing political and economic environment.
\end{abstract}

Keywords: systems theory, human ecology, sustainable rural settlement development, ecovillage design, alternative technologies

This article connects the seemingly unrelated topics of general systems theory, ecological design, and rural settlement in Hungary. These concepts are linked in reference to a practical example. The term "sustainable development" is primarily a political concept. Even after some twenty-five years of use (and often casual abuse by politicians and businessmen seeking to justify business-as-usual scenarios), it still lacks a proper and sound scientific footing (Láng, 2009, 30-59). On the other hand, general systems theory is a scientific discipline established by Ludwig von Bertalanffy and advanced by Fritjof Capra, Francisco Varela, Humberto Maturana, Donella and Denis Meadows, to name only a few (Bertalanffy, 1968; Capra, 1987; Varela et al., 1974; Meadows et al., 1972; Meadows et al., 
1992; Meadows et al., 2004). As opposed to mechanistic and reductionist science, it attempts to apply a different approach based on systems, connections and processes. The emerging new field of human ecology, which attempts to reconcile natural systems with human-made systems, draws boldly on this wealth of knowledge.

One of the findings established by applied systems theory was that human endeavors are chronically infected with positive feedback loops, actions based on inherently uncertain knowledge, and examples of the law of diminishing returns, due to the fact that nature is chaotic and non-linear, as opposed to the mostly logical and linear human and technical systems (Odum, 1997; Marten, 2001). If you aim to establish truly sustainable human communities, you have to adopt these system theoretical features in your design. Bioregionalism is based on the concept that, while establishing conditions suitable for living, humans must take advantage of the resources in the region in which they reside (Sale, 1991). Permaculture is originally an agricultural design scheme, applied later to whole settlements (Mollison, 1988, 1991). The two are united in the term ecovillage, which is by definition a small scale and sustainable human settlement (Gilman et al., 1991). There are numerous ecovillages in the world, the project in Hungary, called Gyürüfü, being one of them.

\section{Systems Theory: A Short Overview}

In nature, living systems are designed in a circular or cyclical pattern, which is very much in line with the revolving and orbiting planet on which we live. The process is shown on Figure 1. The sole source of energy for all systems on Earth,

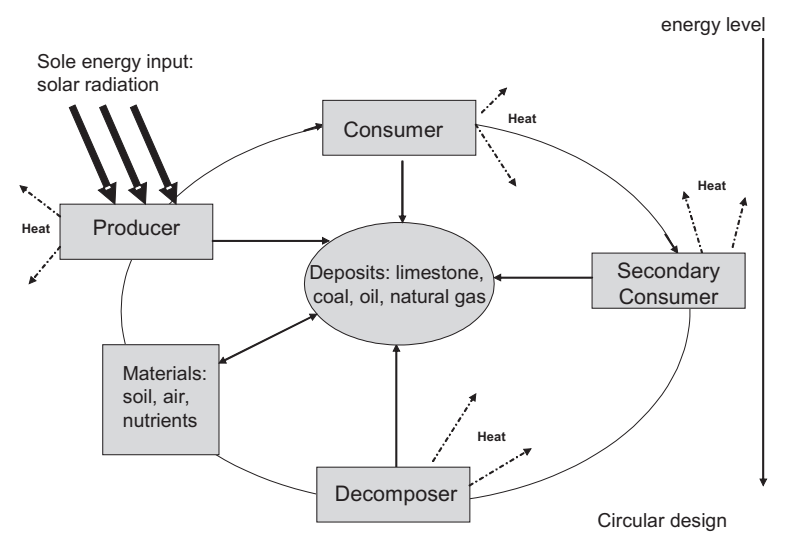

Figure 1. A schematic view of the circular design in natural systems 
with the exceptions of nuclear and geothermal energy, is solar radiation. Living systems are able to capture the energy radiated as electromagnetic waves in the light of the sun and transform it through the process known as photosynthesis into chemically stored energy. Although ecologists define living organisms capable of doing so as producers of an ecosystem, most of us know them as plants. The chemical used for energy storage is also well known: sugar, in the form of starch or cellulose, depending on the molecular arrangement of the polymers. Such secondary energy is consumed, converted and accumulated by other members of the community, in many cases several times over, always loosing a great part in the course of conversion. The rate of loss, which is inevitable according to the second law of thermodynamics, is usually around 1:10. Therefore, in most eco-systems one can distinguish primary, secondary, and even tertiary consumers. Such relationships were formerly customarily depicted in the form of an energy pyramid, because the volume of the biomass and hence the energy stored in it available for the system is reduced from step to step in the food chain. More recently the interconnections of these food systems are recognized as networks, instead of linear chains. This shift in approach is justified by the fact that eventually decomposers break down all organic matter in living organisms into simple compounds and molecules, where it will be available again for use by producers. In all stages of the cycle, some heat is lost and sometimes deposits build up. Deposits from living organisms in various geological times are now known as limestone, coal, crude oil, or natural gas. In fact, these materials are nature's waste from a former stage of the planet's history. It should also be noted that only materials go through this cycle. Energy passes through the system as a flux, increasing the system's entropy. Yet the system is readily and abundantly replenished through sunshine on a long time scale (Postlethwait and Hopson, 1995, 872).

Human society is merely a subsystem of the earth's biosphere. The relationship between the natural environment, society, politics and economics can be seen as a nested hierarchy in the sense discussed by Koestler $(1967,84)$ and Sheldrake $(1987,77)$ and shown in Figure 2. Human-made technical systems provide the opportunity for political and economic subsystems to develop in human society. In human-made technical systems, in particular since the industrial age, external input is also needed in the form of energy and raw materials (see Figure 3). However, such resources are almost exclusively obtained these days from former deposits of living organisms (limestone, oil, gas, coal) or exploitation of non-renewable (metals, ores, rocks) and overexploitation of renewable resources (fisheries, forests, agro-ecological systems, water etc.). There are producers in the anthropogenic systems as well: the manufacturers of goods and service providers. In the next stage, consumers, i.e. users of products and services, reap the perceived benefit from the flow and pass it on to the next stage, which is disposal. In the conversion process from raw materials to products and services and products and ser- 
vices to waste and usage, the major part of the energy and materials involved is lost to the system. There is depletion, but there is no replenishment of either energy or material resources. On the other hand, in each stage there are new forms of deposits created as contamination, pollution and waste: low energy, disorganized materials, which do not have much chance of getting back to the starting point of the process. Decomposers are completely missing from the system. Of course, heat is lost and sometimes secondary use is possible. Yet, the system as a whole is irreversible and linear in design, a one way street. This is why such technical systems are considered to be in host-parasite relationships with the life supporting systems of the planet (Odum, 1997, 314).

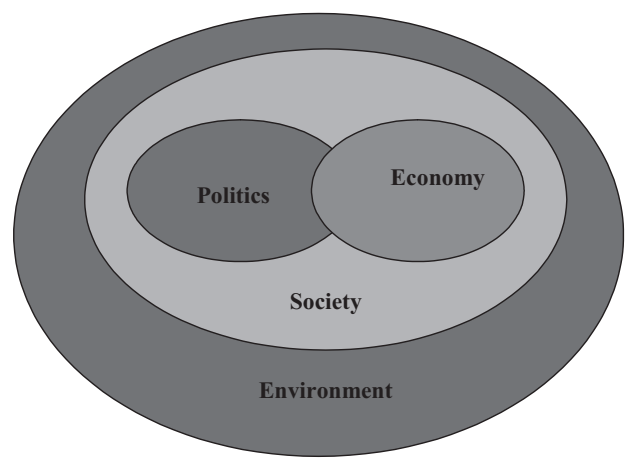

Figure 2. The "nested" hierarchy of the dimensions of sustainability in human communities (Adapted from Balás, 2006)

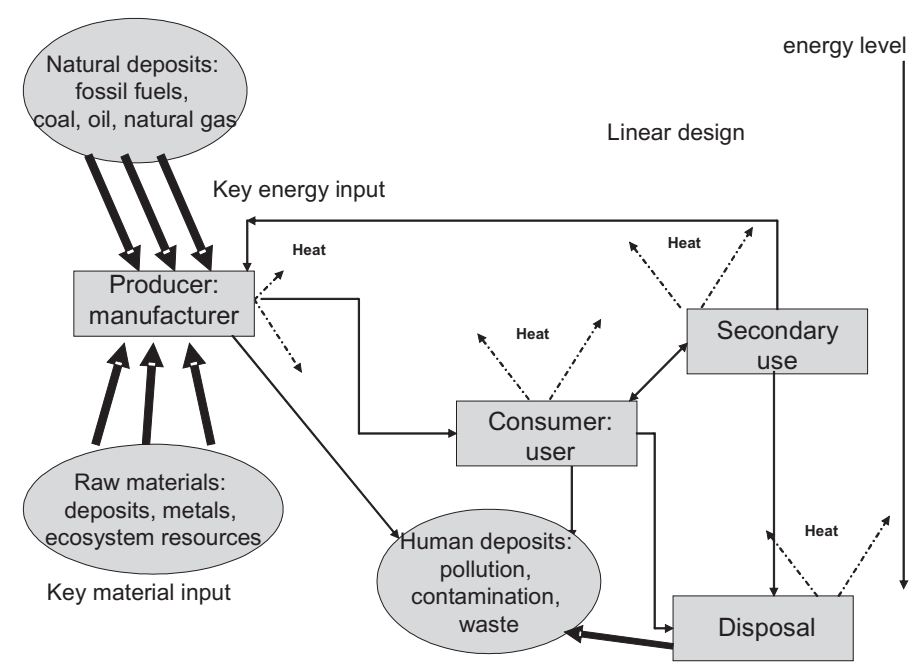

Figure 3. Technical systems are designed in a linear manner 
Human-made technical systems are prone to a typical failure, which is referred to as a type one error in this study. The term is used in a completely different meaning than originally proposed by statisticians to differentiate between false negative and false positive samples (Nyman and Pearson, 1967), and in a slightly different manner later adopted by Mollison in order to avoid mistakes in our dealings with nature (Mollison, 1988, 58). A type one error in this context is a kind of positive feedback loop, forming a vicious cycle and arising from the fact that human-made and ecological systems have been in constant conflict with each other over the course of human history. The loops follow the impeccable logic of positive feedback, as known from cybernetics. During interactions between the social-technological system and the natural systems human needs usually create a problem which is solved by a technical fix: a linear, technical method. The "solution" has an impact on the natural system, which in turn feeds back to the social system, creating an even more complex and comprehensive problem. The new, more advanced solution has an even more detrimental impact on the natural system, which again feeds back to the social system, and so on, in ever growing dimensions and complex consequences. The underlying cause of a type one error is that human technical inventions contrived to overcome the problem have almost always (not only since the industrial revolution) taken simplistic and reductionist approaches, conceived without a holistic system view. They focus on a single component of the various natural systems, which have inherently complex interactions, and they modify or omit the component or add a new one in a single minded insistence on "solving" the problem. However, natural systems, including eco-systems, behave in a complex way and react to such interventions in a system-like manner. The whole system will be rearranged and new boundary conditions will be created. Given that they are completely inflexible, technical solutions cannot be adapted to the new conditions, and they become unfit for the purpose (Borsos, 2003). Good examples include water management practices throughout human history, or the creation by modern medicine of problems it is sometimes unable to address (see Figure 4).

Considering the mechanism of this system, the question arises as to how one might address such a situation by designing social systems with more circumspection instead of "conquering" natural ones. There may be some theoretical considerations which need to be taken into account if a sustainable human system is to be established. First of all, one must avoid technical errors, including overexploitation and overuse, type one errors, and resource waste. Permaculture, bioregionalism and some other concepts and design systems offer a simple principle. They turn the issue upside down, and instead of considering social, human needs (and wishes) as unchangeable, they set up ecologically sound human systems by taking the locally available resources as the guideline for development and adapting the human presence to them. Furthermore, they introduce cybernetic control (nega- 


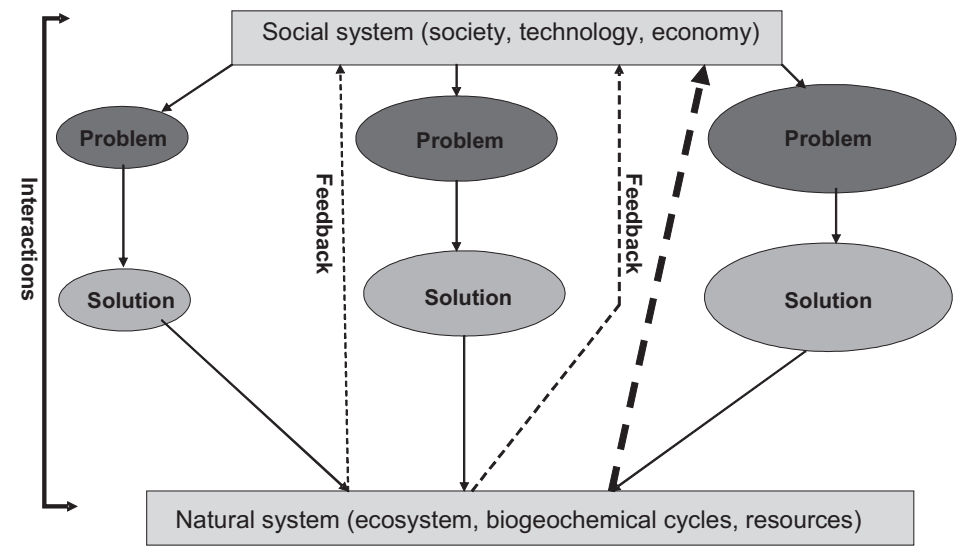

Figure 4. Type one error is based on a positive feedback mechanism arising from the system-theoretical conflict between natural and human-made systems

tive feedback loops) as the basis of regulation, as nature does in ecosystems. A carefully balanced equilibrium of positive and negative feedback ensures healthy development. Planning is made in four dimensions, anticipating the future climax and taking account of the successions as well as the connections between the natural and technical elements in the system. Zones, sectors, and sites for structures are defined according to the existing natural conditions (Mollison, 1988). This way, a genuinely sustainable human system can be developed which is in line with the negative feedback loops of natural systems. An example of this principle in settlement development and design is the ecovillage concept.

\section{The Ecovillage Concept}

What is an ecovillage? It is one of the methods of addressing the challenges of the worldwide ecological crisis through the implementation of sustainable development principles at the rural development level. To put it in another way, it is a means of meeting "the challenge of developing a community living in balanced harmony with itself and with nature," a tough but attainable aspiration (Gilman, 1991). In spite of significant efforts devoted to the development of comprehensive description, there is still no agreed-upon definition of an ecovillage. Instead, there are a number of definitions to choose from, some presented here as the most typical and comprehensive:

An ecovillage is a full-featured settlement in which human activities are harmlessly integrated into the natural world in a way that is sup- 
portive of healthy human development and can be successfully continued into the indefinite future (Gilman et al., 1991).

Ecovillages are human scale settlements, rural or urban, striving to create models for a sustainable lifestyle. They are examples of a development that maintains high quality of life, preserves natural resources and promotes whole system approaches which integrate ecology, education, participatory decision-making, green technologies and businesses.

The current mission statement of GEN (the Global Ecovillage Network) is as follows:

Eco-villages are urban or rural communities of people, who strive to integrate a supportive social environment with a low-impact way of life. To achieve this, they integrate various aspects of ecological design, permaculture, ecological building, green production, alternative energy, community building practices, and much more.

For some, the best model for an ecovillage is the traditional agricultural village. This is an over-simplification of the issue. From the system perspective, traditional villages either work only in areas of low population density, such as slash-and-burn land management practices, or have proven environmentally damaging, as the ecological collapse of many past irrigation-based civilizations demonstrates (Gilman, 1991). Therefore, while traditional agriculture worked in many isolated cases for the particular natural conditions for which they were developed, one cannot subscribe to the generalization according to which the traditional village would constitute a model for ecovillages. Instead, the lessons, both positive and negative, need to be drawn from experience.

True ecovillages, in contrast, are a distinctly post-industrial (and likely even post-agricultural) phenomenon. There are new ecological constraints (such as the need to adapt to the impacts of global climate change), new techniques and technologies (the most obvious being the use of innovative energy production solutions, the capture of solar, thermal, wave, and tidal energy), and new levels of consciousness and awareness, which however sometimes can be counterbalanced by traditional thinking. Given these needs and opportunities, the ecovillage vision entails numerous challenges: the bio-system challenge (habitats, production, land management, waste handling), the built environment challenge (building materials, energy use, space utilization, arrangements), the livelihood challenge (in short, economy and earning a living), the governance challenge (decision making and roles), the "glue" challenge (what will hold it together), and the whole system challenge (a balanced view of all aspects). This requires that sustainability in the true sense be part of the thinking and habits of the villagers from the very beginning. However, taking each of these different aspects into account with equal con- 
sideration presents the greatest challenge of all. Therefore, not surprisingly, ecovillages typically build on various combinations of three dimensions: the social/community aspect, the ecological design and practices aspect, and finally the spiritual (religious)/cultural aspect. Gyürüfü by definition is focused on the ecological design principles and practical examples.

\section{Ecovillages Worldwide}

Ecovillages are scattered around the globe in a wide variety of forms and contents. Ross Jackson, a Canadian turned Danish businessman, decided to devote a large part of his assets to the cause of setting up an international organization with the aim of representing the ecovillage movement in international forums. "We concluded that, more than anything else, the world needed good examples of what it means to live in harmony with nature in a sustainable and spiritually satisfying way in a technologically advanced society" (Jackson, 2009). This is how GEN was established. The global ecovillage strategy was clarified at a meeting in Thy, Denmark. A network was informally initiated with a secretariat in Denmark funded by Jackson's Gaia Trust under the daily leadership of Hamish Stewart. Early members included the Findhorn Community (Scotland), The Farm (Tennessee, USA), Lebensgarten (Steyerberg, Germany) Crystal Waters (Australia), Ecoville (St. Petersburg Russia), Gyürüfü (Hungary), The Ladakh Project (India), The Manitou Institute (Colorado, USA), and the Danish Association of Sustainable Communities. Since then, GEN has grown into a huge global organization with several regions (Ecovillage Network of the Americas (ENA), GEN Europe, GEN Oceania and Asia) and national member networks. GEN Europe includes Africa and the Middle East as well as Russia (Bang, 2005, 13-38).

The member ecovillages represent various social structures, beliefs and ethical principles, some religious and some secular, showing a great diversity themselves, similar to the biodiversity of living systems and ecological communities. Village Homes in Davis, California, for instance, was originally designed by Mike Corbett, an architect and developer who decided to apply permaculture principles to a suburban seventy-acre subdivision (Village Homes, 2009). Crystal Waters, on the other hand, designed by Max Lindegger and others, also in line with permaculture, is situated in a rural landscape in Maleny, Australia, and has all the features of the wilderness, including a little river (Lindegger and Tap, 1989). Ithaca ecovillage focused strongly on community building and is otherwise a suburban division in New York State. Arcosanti lies in the middle of the Arizonan desert and consists of huge vaults cast on the sand of the desert, orchestrated by architect Paolo Solieri. The Farm was originally a hippie community founded by spiritual teacher Stephen Gaskin. The members settled down in rural 
Kentucky and after many developmental phases formed a conscious ecovillage scheme (Fike, 1998). Findhorn in Scotland developed from a spiritual asylum into a settlement of several hundred inhabitants, while Lebensgarten in Germany, near Hannover, converted abandoned military barracks into sustainable homes. The same happened in north-west Italy, where Torri Superiore, a former monastery, was transformed into dwellings and the surrounding agricultural land was farmed by the ecovillage members. Maybe one of the most interesting scenarios is Auroville in Pondicherry, India, which is a spin-off of the Shri Aurobindo ashram (Borsos, 2002).

\section{Objectives for Gyürüfü}

In south-west Hungary the sparsely populated small village region of Zselic is home to a small-scale sustainable settlement development project at the site of the abandoned village of Gyürüfü. The area was resettled over the past fifteen years with strict observation of the principles of ecological design. A small number of ecologically conscious ecovillagers are implementing a comprehensive design scheme on the ground. Ecological landscape assessment of the site preceded the actual design of the project, providing the grounds for proper siting and implementation methods of the various facilities. Alternative solutions were applied to the functions of building construction, building engineering, water management, agriculture, sewage treatment, waste management and gardening. Thus the key objective for the Gyürüfú project is clearly to develop and implement a small scale sustainable settlement development model based on ecological design principles.

During the development of the model, the following tasks were identified: exploration and identification of the relationship between the ecovillage and rural development patterns, the structure of Hungarian settlements, and natural conditions that had to be taken into consideration during planning; resolution to the extent possible of the contradiction between the backward rural area and the new development scheme embedded in it; setting up of a possibly self-sustaining small settlement of approximately 300 inhabitants, open to information and at the same time closed as much as possible in terms of material and energy flows.

\section{The Site}

The site was chosen by taking into account a number of selection criteria, which were partly theoretical principles and partly practical considerations. Thus, for reasons of system integrity the project was thought to be better off when far from urban or suburban impacts on moderately valued land for reasons of better 
securing finances. This put the scope out of the neighborhood of Budapest somewhere deep in the country. In all bioregionalist approaches the desirable site is a stand-alone catchment area in hillsides, so that relatively small drainage would allow for morphological delineation. Low level of industry and transport facilitate the mitigation of any adverse environmental impact. For practical purposes an uninhabited but suitable piece of land was selected. No existing infrastructure or settlement patterns interfered with the design. Small-scale hillside regions are typical of the landscape in Somogy, Baranya, and Zala, counties in south-west Hungary. Of the possible candidate sites, Gyürüfü was finally selected for the reasons described above and for the symbolic name (Gyürüfü has become a symbol of abandoned small villages in Hungary of the 1970s). It consists of a drainage basin of approximately 1,100 hectares with two south-facing hills in the middle and forest covered waterlines around the surrounding higher hills. There is only one outflow from the area to the south where all surface waters discharge. The valleys on both sides of the central hills and the hills themselves were grazed by herds of sheep after the villagers left, the houses fell down, and water wells collapsed. The basic morphological features and the vegetation cover could be clearly seen on the surface contour map and on the vertical aerial photographs made in 1991 at the start of the design work.

Ecosystems have a dynamic development pattern characterized by a set of various successive stages, terminating in a so-called climax state, which is specific for each ecosystem. Abandoned agro-ecological systems, such as the fields of this abandoned village, drift into a secondary succession typical for the individual site. The pattern of ecological succession on an old field shows changes in the vegetation over time that are part of the successive biotic communities which develop in the absence of major natural or human disturbances. First annual "weedy" plants colonize the abandoned plowed ground, followed in a few years by perennials, then shrubs, tree seedlings and finally closed canopy mature forests, which in Central Europe develop over the course of roughly a century (Odum, 1997, 212). The pastures and meadows in and around Gyürúfü were in a highly developed stage of secondary succession at the time the project started.

\section{Key Design Aspects}

"Building a successful eco-village requires a balance of activities among three major phases -1 ) research and design, 2) creation and implementation, and 3) maintenance - for each of the challenge areas" (Gilman, 1991). Two contradictory approaches need to be reconciled in all theoretical concepts endeavoring to develop sustainable settlement development schemes: more efficient use of resources and denser patterns of settlement on the one hand and a natural way of liv- 
ing with adequate space on the other (Hajnal, 2004). Also, a comprehensive vision must be presented, attractive for prospective settlers and at the same time translating as much as possible from the planning and design principles (such as negative feedback, development without growth, biological-ecological compatibility, and so on) into practical solutions. Such practical solutions have to comply with the following criteria:

- The design should be applied to the catchment area (the local drainage)

- Local materials and resources should be used for all activities

- There should be a low level of external input and a high level of labor

- Traditional sustainable methods and new ecological solutions should be combined for optimal results

- Local cycles for materials and energy should be established.

In broad terms, the design process followed the rural environmental planning methods developed by Sargent et al. (1991), starting with the inventory of the resource base, protecting natural areas, keeping (in this case reclaiming) farmland, and planning for the drainage area (the river basin approach), including rural quality and positive social planning. However, when it came to practical implementation, American methods and examples were no longer relevant in Hungary.

When the scope of design had been defined and the watershed of the water catchment area traced (fortunately it largely matched the administrative boundaries), a landscape assessment was made through site visits and field work. In the Zselic hillside region the native mature biotic association would be a dense stand of predominantly sessile oak or durmast oak (quercus petraea) mixed with hornbeam (carpinus betulus). However, due to century-long human presence these woods have been transformed, and in many places they have been replaced by formerly cultivated land, mainly grassland and meadows, and in the valleys by unregulated streams. The former village site is situated in the middle of the water catchment area, on the southern slope of a north-south ridge. Based on the land assessment categories set up by Lóczy and Gyenizse (2003), the Gyürüfú area belongs to group four. It is a range of erosion-derasion hills at an elevation of 250 to 350 meters above sea level, featuring clay-leached brown forest soil and remnants of oak woods with beech and hornbeam, partly under crop.

In the next step of planning, a thorough site investigation was made covering the geology, hydrogeology, and environmental geology, in other words the agro-ecological potential of the site, its farming potential in the permaculture system, the application of the design system on a scattered, clustered village pattern, the state of the forests, design alternatives, water management and waste management concepts, as well as the existing and potential energy infrastructure of the area. Extensive research was carried out in relation to the old Gyürüfü village as 
well. Exploration of the causes for abandonment seemed to prove that, in addition to political causes, emigration was reinforced by the physical geographic situation in the middle of a range of hills, cut off from affordable traffic routes.

Statutory enforcement of the ecological organizing principles seemed to be best served in the middle of the 1990s, at the time the project was designed, by the preparation of a settlement master plan. Land use patterns outlined in the master plan were driven by the desire to reconcile ecological considerations with basic human needs. With the help of overlapping maps the designers tried to identify the sites most suitable for human settlement (i.e. housing plots), in other words the focus was not so much on pre-existing social or infrastructural features, but rather on natural environmental features (such as exposition, aspect, slope categories, inflexion points, forest cover, erosion risk, and so on). The project opted for spacious arrangements, large (one hectare) housing plots, several community areas, and appropriate siting. Due to the natural ruggedness of the landscape, this resulted in a fairly fragmented land use proposal, accompanied with exact requirements for construction methods, land, and landscape use, including arable land, forestry, and water management practices (Farkas, 1995). The first version of the master plan was soon out of date, since it became apparent that the intensive reforestation envisaged by the forestry engineer rendered agricultural land use impossible and was therefore untenable. The master plan was subsequently amended in 2006 in conjunction with the master plan of the neighboring community of Ibafa, the administrative centre, as part of a mandatory review. In order to mark the ecological settlement development pattern, the local government in Ibafa declared the entire watershed a nature reserve (Virányi and Pagony, 2005). Social participation was given strong priority, in particular during the initial planning process.

\section{Energy Management}

Although energy supply was a key aspect of a very complex design challenge, due to the inevitable compromises not all the solutions which otherwise would have been feasible from the technical or physical-geographical perspective could be implemented. The most important shortcoming was that no comprehensive plans were made to replace electricity needs, therefore no feasible, cost efficient alternative was developed to unhook the village from the conventional power grid. Consequently, the electricity needs of the village are still met by use of conventional resources. At the same time, the reduction in the demand for electricity, the use of passive solar energy, the integration of energy from biomass into the system, and the application of energy-saving solutions were all basic objectives during the design phase. 


\section{Building Technology}

The first building permits were issued for Gyürüfü in 1996, after some hesitation concerning the reed bed systems as the waste water treatment method (no standards were in place for such structures at the time) and with the endorsement of the local medical officer on "experimental" grounds. The most important local construction material, the clayey loess soil of the surrounding region, was the most suitable for building the rammed earth houses. Such structures were applied traditionally in most of the local villages. The only substantial improvements to the design of these houses were floating concrete strip foundations with second-hand bricks from demolished buildings as stuffing material. Locally found clay was also suitable to make sun-dried mud bricks, supplemented with a number of other materials, such as mud-plastered straw bricks laid on layers of cardboard insulation for attic flooring, which cannot be standardized or marketed. In addition to the rammed earth construction, houses built of purely mud bricks and light adobe (wooden frames stuffed with mud mixed in straw) were used for most of the buildings.

Considerable emphasis was put on passive solar construction, which included the appropriate orientation of buildings. In the northern hemisphere, south facing windows and heat collecting surfaces such as winter gardens can capture sunlight during the day, and thick walls with high thermal inertia store heat during the night. Heat bridges were eliminated with the use of three layers of glazing and thermal insulation, using sheep wool in and around doors and windows. Walls facing north and north-east were properly insulated by thick reed mats to improve the otherwise poor heat transmission coefficient of the rammed earth walls. As a result, heating needs were reduced during winter, no air conditioning was necessary during summer, and ventilation through the natural movement of air made it unnecessary to use fans.

\section{Building Engineering and Utilities}

One of the most successful implementations of the principle concerning local loops and the use of local materials within the drainage area was seen in the various engineering solutions. In addition to electricity, the only external supply to the system is information in the form of a fixed line telephone service. This is the area in which new needs and technological possibilities most need to be taken into account, therefore even this system is now being gradually replaced with ever more advanced mobile telecommunication systems, including data transmission services. Unfortunately, coverage is poor and currently no broadband internet connection is available. 
On the other hand, a number of conventional utility systems were successfully replaced by more radical alternatives. The entire water management system of the village is independent from any larger scale utilities. There are no water pipes or canalization. Instead, self-reliant water sourcing is implemented from three sources. After the officially required water tests were completed, the water supply was installed from freshly dug wells, purified old groundwater wells, and rainwater collected from rooftops. A third source of clean and healthy drinking water is a nearby spring in the woods. The few gallons of water necessary for drinking and cooking can easily be transported from the spring at any time of year. An interesting finding was the quasi natural cleanup of contaminated groundwater. As the village is located on a hillside consisting of loess, nitrates leaching out of artificial fertilizers and animal manure during the 1970s, when the former village was still inhabited, entered the ground water during the first stage of resettlement, when after some two decades new and former wells were dug and put in operation again. Water from them was first contaminated with nitrates, but the quantity of contaminants quickly dropped to levels difficult to detect after a few years of use. Since replenishment was no longer possible from the local watershed and the groundwater body is not connected to neighboring source systems, it simply has been depleted of the one time contamination. This interpretation is substantiated by the fact that no such problems were encountered on the second hill, where formerly there were no houses or fields of crops, and hence no sources of nitrates (Borsos, 2007, 112).

Since water loops are separated in accordance with intended use, no conventional septic tanks for waste water containment were necessary. In most houses, a separate water pipe system is used for domestic water supply from the water tank, which stores rainwater collected from the rooftops, while drinking water is obtained either from a well or containers filled at the Istenkút spring. And, most importantly, there is no black water in the residential buildings. Human waste is dealt with in dry, composting toilets, which, though they come in a great number of different designs, use no water. Instead, they provide high value compost for gardening. This way domestic waste water remains "grey" in the sense that it contains no human waste and therefore can be treated in reed bed systems, which are attached to each of the houses. In commercial or community facilities such as guest houses or production workshops composting toilets were not endorsed by the competent authorities. Reed beds are still used, but sewage from the flush toilets is first treated with a biologically active agent to degrade feces.

Engineering solutions in the buildings and facilities are as diverse as a real ecosystem. Heating is usually provided by individual wood-fired heating systems, such as cockle-stoves, lime-washed ovens, or natural convection air heating and ventilating systems, all of which usually served additional functions, such as baking or water heating. Domestic hot water generation is primarily based on stoves 
and solar thermo collectors, but some electric heaters are also applied in combination. These systems are excellent implementation examples for the permaculture principle, which provides for design schemes where a particular function is served by several components (water is heated in three different ways) and a particular component addresses a number of functional needs (a single stove may act as a space heater, a central heater, a water heater or, for that matter, an oven in which to bake bread or make coffee).

The construction of the access road to the site was completed in two phases using local sand and rock from a quarry, thus providing connections to the emerging settlement and connecting it to the national network of public roads without much use of fossil resources.

\section{Landscape Management}

Organic farming is a requirement for all farmers on the territory, and ecological principles are enforced in forestry management as well. For instance, clear cutting is prohibited and reforestation is allowed only with native species. A nature conservation management plan was completed for the watershed, providing the framework for the farming and forestry management practices to be applied. As the ecological potential of the land best suits livestock management, sheep, goats, poultry, horses and, of course, feedstuff and forage all have become part of the same agro-ecological system. Mixed farms with orchards, bee-hives, and small livestock such as sheep are also part of the landscape. For reasons of economic viability it is important to generate high value-added products on site, therefore processing is a priority for the agricultural producers. A small processing plant meeting European Union standards produces goat cheese, cottage cheese, yoghurt and butter, while another facility produces mainly marmalades and jams from the orchard in which it is situated.

\section{Biodiversity, Habitats}

Another design principle requires that people should not only preserve, but enrich the biotope in which they live, and also demonstrate how they live. The success of the ecovillage concept at Gyürüfü is made clear by the fact that on Hungarian Biodiversity Day, organized for the first time in 2006 and a second time in 2007 by the Hungarian Association of Ornithologists and the Gyürüfü Association, 24 field scientists managed to identify a total of 1,656 multi-cellular species of animal, plant and fungus, much more than previously anticipated, over a 24 hour period in the Szentlélek valley on a plot a mere one square kilometer in size. 
People living here have always made a point of demonstrating the model value of the village. In Spring 2007 the Szent László nature conservation trail was opened, providing an excellent summary of the various events and occurrences taking place at Gyürüfü with the help of an open air exhibition and a two kilometer path in and around the site.

\section{Social Engineering}

The project put great emphasis on community building from the outset. Unfortunately, however, the organisational structure did not live up to the high hopes of the participants. For many years the only social structure in place was a private foundation established by the originators of the initiative. A foundation, however, has no membership, and therefore project participants organized themselves in an association first, and later a committee of the local council took over many of the responsibilities of the foundation. The ownership structure was also unfortunate, as the foundation owned the land in the core territory of about 174 hectares where the housing plots were situated. At first people who wished to settle in the area had to do so within the framework of a leasing scheme, and only later, after several conflicts had come to the surface, were they actually able to purchase the grounds designated for private residential use. In the meantime, changes in national legislation made organisation of the ownership structure and land use even more difficult. Political considerations of re-privatization of arable land after the political transition also played an adverse role.

\section{Results and Evaluation}

When evaluating the results, the need for sustainable development and the outlook for the project have to be taken into consideration. According to O'Sullivan (2000),

for local authorities attempting to provide land for housing and rejuvenate depopulated rural areas, while at the same time trying to control unsuitable developments, the advantages of [...] eco-village development are:

- infrastructure requirements are minimal, since eco-villages take care of their own water supplies and wastes;

- public authority sewage and water treatment capacity can become available to serve other needs; 
- road traffic generated by a sustainable settlement is much less than would be generated by the same number of persons living in conventional housing;

- eco-villages provide employment in rural areas, based on renewable natural resources (organic horticulture and farming) and on the use of high-technology equipment and skills (teleworking);

- sustainable settlements can provide affordable permanent housing $[\ldots]$;

- settlements on some locations may contribute to eco-tourism by providing visitor attractions, educational activities and leisure opportunities $[\ldots]$;

- children from sustainable settlements help increase numbers attending local schools $[\ldots]$;

- sustainable eco-villages provide models of appropriate forms of living $[\ldots]$ and they serve as pilot projects for testing environmentally friendly building techniques, low impact housing, zero-waste life-styles and other sustainable activities.

If one regards the considerations above as a kind of check list for a successful ecovillage, Gyürüfü can be said to have been a success.

It is nonetheless difficult to disregard practical constraints when comparing the theoretical requirements derived from the system theoretical considerations with the implementation results of a project subject to a number of external factors beyond its control. Since eco-design is fundamentally local, you cannot regulate it centrally. Yet in Hungary, as well as in many other parts of the world, bureaucratic control is gaining ground in ever more aspects of life. Also, local means small, as opposed to conventional economic activities. Globalization in the business sphere is counterproductive to any bio-regionalist approach. A degree of freedom is needed to have several options in design and implementation alike. In an overregulated environment prone to overwhelming trade and commercial interests, it is becoming increasingly difficult to maintain such options. Gyürüfü came into being at a historical juncture, in the political transition environment of the early 1990 s, a moment in political history which is not easy to replicate. Yet it has a value as a model.

Sustainability indicators were applied in a very simple attempt to assess the success of the project. Only one rough and by no means reliable attempt was made to measure the sustainability of the ecovillage so far. Unlike the on-line questionnaire of GEN (Community Sustainability Assessment, 2009), it took into account political considerations, in addition to the environmental, ecological, social and economic indicators. This attempt indicated that many of these values differ from those of a conventional Hungarian community. Unfortunately, in the absence of an experimental control, these data are of interest only as anecdote. In addition to the fact that the evaluation was based on very rough estimates and no actual mea- 
surements were carried out, further difficulties were raised by the incomparability of the various units of measurement. This problem could be addressed by putting the values obtained on an imaginary scale of 100 . Upon evaluation of the individual scores, weighting was used to indicate the relative importance of the property in question. Based on this sketchy picture, the state of sustainability at Gyürüfü (illustrated in Figure 5) seems doubtful from the social and political perspective, and its economic sustainability is threatened dramatically by a number of external factors (Balás, 2006).

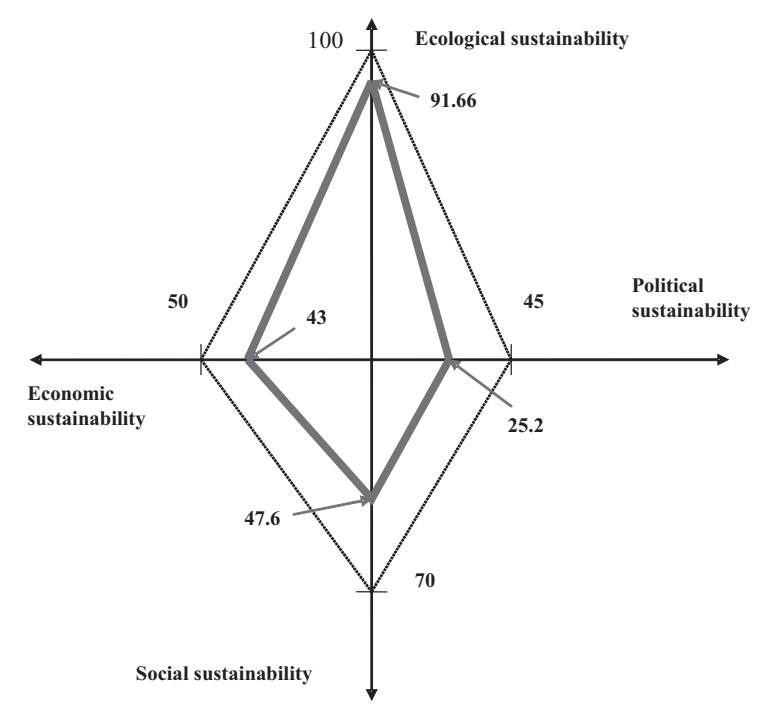

Figure 5. Gyürüfü's balanced sustainability footprint (Adapted from Balás, 2006)

\section{Conclusions}

In the case of Gyürüfú, community building and the strengthening of social relationships were neglected in favor of aspects of physical design. Due to external factors, such as political conditions, and internal factors, including inexperience and lack of internal cohesion, the ownership structure of the project, in particular land ownership, became extremely confused, which rendered the application of consistent land use patterns difficult. In order better to adhere to ecological principles, the regulatory environment must be adapted through the establishment of a flexible, transparent organizational structure, and existing opportunities must be exploited to the full extent possible. Finally, from the scientific point of view, appropriate sustainability indicators need to be established and used for evaluation of the results. 
In summary, as is usually the case with living systems, stability and variability are present simultaneously in the development patterns of a community focusing on ecological principles of organization. It is testimony to the viability of the project that it was able to respond adequately to the challenges faced so far and preserve its original ecological features, while it also remained able to adapt in order to avoid the traps of inevitability. Provided it can preserve the strengths and improve on the weaknesses, there is good reason to hope that the project will continue in the right direction.

\section{Acknowledgements}

I would like to give thanks to Ágnes Fülemile for organizing the conference at Indiana University, Bloomington entitled "Landscape, Environment and Society - Past and Present Environmental Issues in Hungary, 29th György Ránki Hungarian Chair Symposium," where a preliminary version of this paper was presented. Also, I would like to express my gratitude to the various people who have participated in or contributed to the experiment at Gyürüfü. Finally, I am grateful to my family, who have patiently endured the trials and tribulations entailed in building an ecovillage, and bearing with me while I wrote the present paper.

\section{References}

Balás, D. (2006) Balanced Sustainability in Rural Communities. Christelijke Agrarische Hogeschool. CAH Dronten Professional Agricultural University Rural Development.

Bang, J. M. (2005) Ecovillages. A Practical Guide to Sustainable Communities (Gabriola Island, VA Canada: New Society Publishers).

Bertalanffy, L. (1968) General System Theory. New York: Braziller.

Borsos, B. (2003) Azok a bizonyos könnyü léptek I. Ökológia és rendszerelmélet (Tread Lightly on Earth I. Ecology and Systems Theory) (Budapest: L'Harmattan).

Borsos, B. (2003) Ázsiától Ázsiáig (From Asia to Asia) (Budapest: L'Harmattan).

Borsos B. (2007) Az ökofalu koncepciója és helye a fenntartható település- és vidékfejlesztésben (The Ecovillage Concept and its Place in Sustainable Settlement and Rural Development). Doctoral Dissertation. Pécs: Pécs University of Sciences, Faculty of Natural Sciences, PhD School of Geography Sciences, Pécsi Tudományegyetem Természettudományi Kar Földtudományok Doktori Iskola.

Capra, F. (1997) The Web of Life. A new systhesis of mind and matter (London: Flamingo).

Community Sustainability Assessment questionnnaire: http:/gen.ecovillage.org/activities/csa/pdf/ CSA-English.pdf. Downloaded on 6th May, 2009

Farkas, G. (1995) Ibafa-Gyürüfü összevont rendezési terve (Integrated Master Plan for Ibafa-Gyürüfü). Manuscript.

Fike, R. (ed.) (1998) Voices from the Farm. Adventures in Community Living (Summertown, Tennessee: Book Publishing Company).

GEN (2009): http://gen.ecovillage.org/about/index.html. Retrieved on 2nd December, 2009

Gilman, R. (1991) The Eco-village Challenge. Living Together. IC No. 29. Summer 1991. 
Gilman, R. and Gilman, D. (1991) Ecovillages and Sustainable Communities: A Report for Gaia Trust by Context Institute (Snedsted, Denmark: Gaia Trust).

Hajnal, Klára (2004) A fenntartható fejlödés elméleti modellje és a fenntartható településfejlesztés elméleti kérdései (A Theoretical Model of Sustainable Development and Theoretical Issues in Sustainable Settlement Development) PhD dissertation thesis (Pécs: Pécs: Pécs University of Sciences, Faculty of Natural Sciences, PhD School of Geography Sciences, Pécsi Tudományegyetem Természettudományi Kar Földrajzi Intézet, PTE, Institute of Geography, 184)

Jackson, R. (2009) The history of GEN. http://gen.ecovillage.org/about/index.html Downloaded on 6th May, 2009.

Koestler, A. (1967) A Ghost in the Machine (London: Hutchinson \& Co.).

Láng, I. (2009) Félreértett üzenet (Message misread) in Mária Kóródi (ed.) Az eröszak kultúrája. Fenntartható-e a fejlödés? (The cult of violence. Is development really sustainable?) (Budapest: Pallas Publishing House).

Lindegger, M. and Tap, R. (1989) Conceptual Permaculture Report, Crystal Waters Permaculture Village (Nambour, Queensland: Nascimanere Pty Ltd.) 80.

Marten, G. G. (2001) Human Ecology: Basic Concepts for Sustainable Development (London Sterling, VA: Earthscan).

Meadows, D. H., Meadows, D. L. and Randers, J. (1992) Beyond the Limits - Confronting Global Collapse and Envisioning a Sustainable Future (Post Mills, Vermont: Chelsea Green Publishing Company).

Meadows, D. H., Meadows, D. L., Randers, J. and Behrens, W. W. (1972) The Limits to Growth - A Report for the Club of Rome's Project on the Predicament of Mankind (Washington: Potomac Associates. London: Earth Island Ltd.).

Meadows, D. H., Meadows, D. L., and Randers, J. (2004) Limits to Growth-The 30-Year Update (White River Junction, Vermont: Chelsea Green).

Mollison, B. (1988) Permaculture, A Designers' Manual (Tyalgum, Australia: Tagari Publications).

Mollison, B., 1990. Permaculture: A Practical Guide for a Sustainable Future (Washington: Island Press).

Neyman, J. and Pearson, E. S. (1928) On the Use and Interpretation of Certain Test Criteria for Purposes of Statistical Inference, Part I in J. Neyman and E. S. Pearson (1967) Joint Statistical Papers (Cambridge: Cambridge University Press) 1-66.

O'Sullivan, J. (2000) Creating Sustainable Human Settlements - An Ecological Solution N(avan Chamber of Commerce: 9th National Environmental Conference: Promoting Sustainable Development Partnerships and Coping with Population Changes, Navan).

Odum, E. P. (1997) Ecology: A Bridge between Science and Society (Sunderland, USA: Sinauer Associates Inc.).

Postlethwait, J. H. and Hopson, J. L. (1995) The Nature of Life (New York: McGraw-Hill Inc.).

Sale, K. (1991) Dwellers in the Land, The Bioregional Vision (New York: New Society Publishers).

Sargent, F. O., Lusk, P., Rivera, J. A. and Varela, M. (1991) Rural Environmental Planning for Sustainable Communities (Washington, D.C., Covelo, CA: Island Press).

Sheldrake, R. (1987) A New Science of Life. The Hypothesis of Formative Causation (London: Paladin Grafton Books).

Varela, F., Humberto, M. and Uribe, R. (1974) Autopoesis: The Organization of Living Systems, its Characterisation and a Model. BioSystems, Vol. 5, 187-96.

Village Homes (2009) http://www.villagehomesdavis.org/public/about. Downloaded on 22 May, 2009.

Virányi Építész Stúdió Kft. - Pagony Kft., (2005). Ibafa területrendezési terve Jsz: 5/2003, 2.3: Gyűrüfü szabályozási terv, Manuscript (Master Plan for Ibafa. Ref. No. 5/2003, 2.3: Zoning Plan for Gyürüfü). 